\title{
Isolation and Characterization of Cellulolytic Marine Bacteria for Litopenaeus Vannamei Aquaculture Using Sugarcane Bagasse as Carbon Source
}

\author{
Wei Ren \\ Hainan University \\ Xueni Xu \\ Hainan University \\ Hao Long \\ Hainan University \\ xiang Zhang \\ Hainan University \\ Xiaoni Cai \\ Hainan University \\ Aiyou Huang \\ Hainan University \\ Zhenyu Xie ( $\nabla 1004570447 @ q q . c o m$ ) \\ Hainan University
}

\section{Research}

Keywords: Cellulolytic marine bacteria, Sugarcane bagasse, Litopenaeus vannamei aquaculture, Hydrolysis capacity, Antibiotic susceptibility

Posted Date: August 31st, 2020

DOI: https://doi.org/10.21203/rs.3.rs-67558/v1

License: (c) (i) This work is licensed under a Creative Commons Attribution 4.0 International License. Read Full License 


\section{Abstract}

Background: In aquaculture system, it is essential to adjust the inherent disadvantage of $\mathrm{C} / \mathrm{N}$ ratio by adding a lot of additional carbon sources, such as sugarcane molasses, organic acids, and organic acid salts, which will greatly increase the cost of shrimp aquaculture. Herein, we aimed to isolate cellulolytic marine bacteria to hydrolyze sugarcane bagasse (SB) for reducing the cost of addition of external carbon sources in industrial Litopenaeus vannamei aquaculture.

Results: A total of 97 cellulolytic marine bacterial strains belonged to 6 genera were isolated from 2,585 indigenous bacteria, indicating that seagrass bed can be used as an important place for screening the cellulolytic bacteria. The hydrolysis capacity $(\mathrm{HC})$ of 58 cellulolytic marine bacterial strains was ranged from 1.1-4.0. MW-M5 displayed the largest $\mathrm{HC}$ value, followed by MW-M10 and MW-M14. The cellulase contents of 30 strains were more than $3 \mathrm{U} / \mathrm{g}$ in the supernatant of fermentation broth after $24 \mathrm{~h}$, which was significantly higher than that of commercial cellulose. 26 cellulolytic marine bacteria with $\mathrm{HC}$ greater than 2 were safe for L. vannamei. MW-M19 with the lowest multiple antibiotic resistance index, 0.1 , had a highest SB enzyme activity, $4.14 \mathrm{U} / \mathrm{mL}$. The SB decomposition rates of CFW-C18 and MW-M15 were up to about $63.81 \%$ and $48.57 \%$ after fifteen days, respectively.

Conclusions: These results provide valuable information for further construction of a shrimp aquaculture system based on low-cost external carbon sources using cellulolytic bacteria, and even for other biotechnological applications.

\section{Background}

Litopenaeus vannamei, also known as Pacific white shrimp or King prawn, which has become one of the pillar industries in the agricultural economy of most coastal areas [1, 2]. It is also one of main prawn species in China. Due to its high economic value, delicious meat, rich nutrition, low-feed conversion rate, high survival rate, low water consumption, and short growth cycle, L. vannamei is considered a good alternative [3]. With the change of aquaculture environment and facility and the improvement of aquaculture technology, the mode of L. vannamei aquaculture experienced a gradual change from extensive aquaculture to intensive aquaculture. However, the intensive aquaculture has been restricted because of the eutrophication of water [4], such as nitrogen and phosphorus enrichment and organic deposition [5, 6], which indirectly led to harmful algal blooms [7-10]. In order to pursue high yield and income, some operations blindly increased the scale of aquaculture and put in bait and fertilizer containing a large amount of nitrogen and phosphorus, which led to water deterioration and frequent disease. In recent years, a large amount of nitrogen and bait remained in the aquaculture system couldn't be used in the process of L. vannamei aquaculture, and then the accumulated biological excreta and inedible feed in the aquatic environment will be decomposed into high concentrations of nitrogen compounds, such as ammonia and nitrite [11-13]. The increase of total nitrogen content in water leads to the decrease of $\mathrm{C} / \mathrm{N}$ ratio and the lack of carbon content, which makes it difficult for microorganisms to survive and inhibit the assimilation of heterotrophic microorganisms $[3,14]$. Ammonia nitrogen and nitrite nitrogen will decrease with the increase of $\mathrm{C} / \mathrm{N}$, and the denitrogen rate of bacteria will furtherly increase with the increase of $\mathrm{C} / \mathrm{N}$ [15].

Currently, biological treatments in tail water of aquaculture have become a research hotspot. Some researchers reported that Bacillus could improve water quality, increase the survival rate and health of prawns, and prevent the outbreak of pathogenic Vibrio [16]. The bio-floc technology provides a method to solve the shortage of protein feed 
resources and the persistent organic pollution. There is no need to exchange water or a small amount of water exchange in the process of intensive aquaculture, thereby improving sustainability of the aquaculture system, biological safety, and production of aquaculture [17]. In this system, carbon source is supplemented according to the characteristics of microorganisms to maintain water quality, which can promote the growth of heterotrophic bacteria, remove inorganic nitrogen from the water, and maintain water balance [18, 19]. In addition, the feed containing cellulase has been paid more and more attention in the industrial aquaculture in recent years. The nitrogen that can be used by prawns is actually very limited in the process of prawn aquaculture, and the nitrogen of the high-protein bait deposited in the bottom mud will make the water turn black. However, the inorganic nitrogen in the experimental shrimp ponds can be reduced by adding carbon source. The process mainly transforms nitrogen into protein required by microorganisms as the source of feed protein for $L$. vannameito avoid the accumulation of inorganic nitrogen in water body. The exogenous carbon sources can promote the growth of microorganisms in aquaculture and provide the required carbon source to form bio-flocs, which will further meet the ingestion of prawns and reduce the accumulation of toxic inorganic nitrogen compounds [20-22]. It is a practical and cheap method to control inorganic nitrogen by controlling $\mathrm{C} / \mathrm{N}$ ratio in aquaculture system. If the $\mathrm{C} / \mathrm{N}$ ratio in water is too high, a part of nitrogen will be used by bacteria to synthesize protein. Especially in the later stage of cultivation, the additional carbon sources, such as sucrose and molasses, can increase the $\mathrm{C} / \mathrm{N}$ ratio, promote the growth of heterotrophic bacteria, enrich the diversity of bacteria, improve the aquaculture environment, and increase the total production of aquaculture $[18,19,22,23]$.

Therefore, it is an effective method to improve the yield of $L$. vannamei and solve the water pollution by adding exogenous carbon sources in the aquaculture system to adjust the $\mathrm{C} / \mathrm{N}$ ratio. The carbon sources supplemented in aquaculture mainly include sucrose, glycerin, glucose, and sodium acetate [24-26]. However, these carbon sources are expensive and easy to cause environmental pollution. Accordingly, it is urgent to find cheap carbon sources for long-term feeding in aquaculture. Sugarcane is a widely grown sugar crop in Hainan, China, and its bagasse is the main wastes of sugar industry. Sugarcane bagasse (SB) as major by-product of sugar industry, in general, about 260-280 kg wet SB produced from per ton sugarcane, with total production of more than 279 MMT tons annually worldwide $[27,28]$. About $40-50 \%$ of dried SB is cellulose, while it is very difficult for this polysaccharide to decompose because of its stable chemical linkages inside a monomeric cellulose chain, as well as the crystalline structure formed by multiple cellulose microfibrils that are interconnected by hydrogen bonds [29]. Cellulose is the most abundant organic matter on the earth and characterized by cheap and easily available carbon source. Microbial cellulolytic enzymes, called cellulase, are complex enzymes that consist of endoglucanases, exoglucanases and $\beta$-glucosidases, which synergistically work to hydrolyse the $\beta-1,4$ glycosidic bonds of cellulose [30]. Most cellulolytic enzymes with high activity used in commercial applications are produced from fungi [31]. By contrast, bacteria have higher growth rate and enzyme production rate than that of fungi. More importantly, bacteria have higher thermal stability and genetic stability than that of fungi [32]. In addition, the oceans, which covers more than three quarters of the Earth's surface, is an open ecosystem. It has been estimated that at least $50 \%$, and potentially more than $90 \%$, of all marine species are undescribed [33-36]. Marine microorganisms have been recognized as potential sources of novel enzymes with better biocatalytic properties than their terrestrial counterparts. These properties, such as salt tolerance, hyperthermostability, barophilicity, alkali-resistance, and low optimum temperatures, are necessary for efficient bioprocesses exploitation [33-36]. Hainan is a big maritime province in China and rich in marine resources, but the knowledge of cellulolytic microbes isolated from this area is limited. At present, it is necessary to add a lot of additional carbon sources to adjust the inherent disadvantage of $\mathrm{C} / \mathrm{N}$ ratio in aquaculture system, such as sugarcane molasses, organic acids, and organic acid salts [23, 37, 38], which will greatly increase the cost of shrimp aquaculture. To overcome these problems, the marine bacteria 
demonstrating SB cellulolytic performance were isolated from the alongshore of the Hainan Province, China, which were suitable for tropical marine aquaculture. The purpose was to determine competent cellulolytic marine bacteria for SB decomposition as the low-cost external carbon source in L. vannamei mariculture system.

\section{Results}

\subsection{Isolation, screening, and identification of cellulolytic marine bacteria}

A total of 2,585 marine bacteria with dissimilarly morphological colonies were isolated from four sites in Hannan (Table 1). Among them, ninety-seven bacterial isolates were defined as cellulolytic bacteria because they exhibited the cellulolytic zone around their colonies on 2661E agar after Congo red staining, which were belonged to 6 genera (Fig. 1 and Table S2). The largest genus was Bacillus (64\%), followed by Vibrio (18\%). The remaining genera were shared by Microbulbifer(10\%), Pseudomonas (6\%), Tenacibaculum (1\%), and Muricauda (1\%). We found that the cellulolytic bacteria were mainly from the natural environments (seagrass beds of Mangrove and Dongjiao Coconut Forest). However, there were only 6 cellulolytic bacteria isolated from aquaculture environments (two shrimp cultural bases). As shown in Fig. 1, Bacillus was accounted for the most in natural environment and aquaculture environment, followed by Vibrio. Interestingly, Vibrio, Pseudomonas, and Microbulbifer were only isolated from the natural environment, while Tenacibaculum and Muricauda were only isolated from the aquaculture environment.

\subsection{Cellulolytic activity of cellulolytic marine bacterial strains}

At present study, there were 97 marine bacterial strains showing FPase activity (Table S2). MW-C57 belonging to Bacillus had the highest FPase activity, $2.325 \mathrm{U} / \mathrm{mL}$. The FPase activities of other marine bacteria from this study areas were ranged from 0.018 to $0.597 \mathrm{U} / \mathrm{mL}$. Of the 97 marine bacterial strains, only 58 strains had $\mathrm{HC}$ values more than 1 (Table 2). Among them, MW-M5 displayed the largest HC value (3.951), followed by MW-M10 (HC value=3.752) and MW-M14 (HC value=3.505). In addition, there are 6 strains with $\mathrm{HC}$ value greater than 3,7 strains with $\mathrm{HC}$ values ranged from 2.5 to 3,15 strains with $\mathrm{HC}$ values ranged from 2 to 2.5 , and 29 strains with $\mathrm{HC}$ values ranged from 1 to 2. Based on the linear relationship (Fig. S1 and S2) between $\mathrm{HC}$ value and content of commercial cellulase from Aspergillus niger(TCl-Tixi Ai (Shanghai) Chemical Industry Development Co., Ltd., Shanghai, China), the cellulase production from 58 strains were quantified (Table 2).

\subsection{Screening ofthe safe cellulolytic marine bacteriafor $L$. vannamei aquaculture}

\subsubsection{Safety of cellulolytic marine bacteria to L. vannamei}

In this study, of the 28-test cellulolytic marine bacteria except CFW-C9 and MW-C47 were harmless to shrimp as no mortality was observed by subjecting the test animal, $L$. vannamei to high density $\left(10^{-7} \mathrm{CFU} \mathrm{mL}^{-1} \mathrm{water}\right)$ immersion challenge of cellulolytic marine bacteria for consecutive 7 days (Table 3).

\subsubsection{Antibiotic susceptibility assay}

The antibiotic susceptibilities of 28 cellulolytic marine bacteria belonging to three genera (22 strains of Bacillus, 4 strains of Vibrio, and 1 strain of Micrococcus) were measured with 30 kinds of antibiotics (Table S3). As shown in Table 4, 82.14\% cellulolytic marine bacteria were susceptible to chloramphenicol (Table 4 ). $50 \%-80 \%$ cellulolytic marine bacteria were intermediate resistant to tested antibiotic, such as cefoxitin (67.86\%), ceftriaxone (78.57\%), 
neomycin (53.57\%), oxytetracycline (57.14\%), and furazolidone (50\%). 80\%-93\% cellulolytic marine bacteria were resistant to tested antibiotic, such as penicillin (89.29\%), oxacillin (89.29\%), piperacillin (89.29\%), carbenicillin (82.14\%), cefalexin (82.14\%), streptomycin (85.71\%), spectinomycin (82.14\%), tetracycline (92.86\%), erythromycin (85.71\%), and azithromycin (85.71\%). 77.27\% of Bacillus bacteria were sensitive to phenylpropanol chloramphenicol, and $100 \%$ of Vibrio and Microalcoccus bacteria were sensitive to chloramphenicol (Table 4). The strains were performed strong resistance to some antibiotics with higher MAR Index, such as penicillin (0.89), piperacillin (0.89), carbenicillin (0.82), cefalexin (0.82), streptomycin (0.86), spectinomycin (0.82), tetracycline (0.93), erythromycin (0.86), and azithromycin (0.86). Antibiotic-resistant bacteria in mariculture farms may be transported by water current which flows from surrounding farms that utilize antibiotics excessively. These strains were not resistant to some antibiotics with lower MAR index, such as cefoxitin (0.18), ceftriaxone (0.14), chloramphenicol (0.04), and furazolidone (0.18). MW-M19 belonging to Vibrio with a lowest MAR index (0.1) was resistant to only three antibiotics, while MW-C47 belonging to Bacillus with a highest MAR Index (0.93) was resistant to 28 kinds of antibiotics (Table 3 and S3).

\subsection{Determination of the SB decomposition of the safe cellulolytic bacteria}

In this study, SB powder with diameter of $0.05-0.1 \mathrm{~mm}$ was used as the sole carbon source, and then evaluated the ability of SB decomposition of cellulolytic marine bacterial strains in order to lay the foundation for providing cheap carbon sources to aquaculture in the future. As shown in Table 3, MW-M19 has the highest SBase (4.14 $\mathrm{U} / \mathrm{mL}$ ). The SBases of MW-C77, MW-C44, MW-C79, and MW-M17 were $3.746 \mathrm{U} / \mathrm{mL}, 2.152 \mathrm{U} / \mathrm{mL}, 1.952 \mathrm{U} / \mathrm{mL}$, and $1.75 \mathrm{U} / \mathrm{mL}$, respectively. 26 cellulase producing strains were inoculated with SB as the sole carbon source, and the SB decomposition rate of each strain was also determined after 15 days. As shown in Table 3, the SB decomposition rates of 8 cellulolytic marine bacteria had no significant difference compared with that of control. The SB decomposition rates of 14 cellulolytic marine bacteria were more than $30 \%$. Among them, the SB decomposition rates of CFW-C18 and MW-M15 were up to $63.81 \%$ and $48.57 \%$, respectively.

\section{Discussion}

\subsection{Isolation, screening, and identification of cellulolytic marine bacteria}

The South China Sea (SCS) is vast, covering more than 2 million square kilometers, which is one of the largest marginal seas [39] with rich microbial resources in the world. There are a lot of seagrass ecosystems in SCS. Seagrass ecosystems are considered major blue carbon sinks, which occupy less than $0.2 \%$ of the area of the world's oceans but are estimated to bury roughly $10 \%$ of the yearly estimated organic carbon burial in the oceans $[40,41]$. Seagrass bed is also a marine ecosystem with high microbial diversity, and the cellulose is one of main organic matter [42]. Therefore, we reason that bacteria with highly cellulolytic activates are likely to exist in these marine ecosystems. However, the knowledge of cellulolytic marine bacteria from Hainan seagrass beds is limited. Herein, our aim is to isolate cellulolytic marine bacteria for $L$. vannamei aquaculture from these areas to reduce its cost by hydrolyzing SB. 91 cellulolytic marine bacteria of 97 cellulolytic isolates were from seagrass bed ecosystems, indicating that seagrass beds can be used as an important place for screening the cellulolytic bacteria. These results indicated that Bacillus and Vibrio were the dominant cellulolytic bacteria in seagrass ecosystems. In addition, although we only obtained 6 cellulolytic bacteria from aquaculture environments, there were 4 strains belonging to Bacillus, indicting that Bacillus was also the dominant cellulolytic bacteria in aquaculture ecosystems. 
Most cellulolytic enzymes isolated from mangrove were from bacteria belonging to the genera Micrococcus, Bacillus, Pseudomonas, Xanthomonas, and Brucella [43, 44]. The cellulolytic bacteria isolated from different areas have different properties. The cellulolytic bacterium from farm at Zhanjiang (Guangdong Province, China), Lactobacillus pentosus AS13, can effectively enhance the growth performance, feed utilization, digestive enzymes and disease resistance of L. vannamei [45]. Geobacillus thermodenitrificans IP_WH1 from North West Himalayas could produced a thermotolerant cellulase [46]. Therefore, these cellulolytic marine bacteria from the tropical marine environment may be also characterized by potential use.

So far, more researches on mesophilic and thermophilic cellulases have been reported, while fewer works were on low-temperature cellulase. Low-temperature enzymes can not only ensure high-efficiency enzyme reactions at lowtemperature, but also inactivate enzymes at low-temperature, thereby saving energy and cost in the production process. The probability of developing low-temperature cellulase from terrestrial organisms is much lower than that from marine organisms. The marine environment is very unique. Marine microbial enzymes are usually identified by cold tolerance and salt-alkali resistance, and have unique application prospects compared with terrestrial microbial enzymes. Therefore, the cellulolytic marine bacteria from marine environments may be have more potential applications than those from terrestrial, particularly on mariculture.

\subsection{Cellulolytic activity of cellulolytic marine bacterial strains}

Cellulases are mainly divided into endoglucanases, exoglucanases and $\beta$-glucosidases, and the three enzymes act synergistically in cellulose hydrolysis [30]. The cost of cellulolytic enzymes is a major factor in the hydrolysis of lignocellulosic materials to fermentable sugars [47]. Currently, various cellulolytic microorganisms were from fungi, such as Aspergillus [48, 49], Penicillium [50, 51], Trichoderma [30, 52-54], and Talaromyces [55-57], which required long production cycles. Compared with fungi, bacteria not only have a higher growth rate, but also produce cellulase in a short time. At the present study, the highest FPase activity of Bacillus MW-C57, 2.325 U/mL, was 18-fold higher than that of NAB37 from Haryana [58]. Unfortunately, MW-C57 didn't display HC. The FPase activity of other marine bacteria from this study areas was similar to that from Haryana [58]. The FPase activities of our marine bacteria, 0.018 to $0.597 \mathrm{U} / \mathrm{mL}$, were lower than that of fungi, for example, the FPase of T. harzianum belonging to fungi was in the range of $0.445-2.7 \mathrm{U} / \mathrm{mL}[30]$.

In this study, a total 28 cellulolytic marine bacterial strains with $\mathrm{HC}$ value greater than 2 were classified as high enzyme activity strains, which were used for further screening the safe cellulolytic marine bacteria for L. vannamei (Table 3). The cellulolytic marine bacterial with the largest $\mathrm{HC}$ value were isolated, namely MW-M5 (HC value=3.951), MW-M10 (HC value=3.752), and MW-M14 (HC value=3.505). The HC values of cellulose degrading bacteria from mangrove soils were ranged from 1.25 to 2.5 [43], which were very similar to that from flower stalksvegetable waste co-composting system (HC values were ranged from 0.4 to 2.1) [59]. HC values of cellulolytic bacteria from oil palm were ranged from 1.56 to 4.14 [60].

It is worth noting that there were 30 strains with the relative enzyme content (REC) more than $3 \mathrm{U} / \mathrm{g}$ in the supernatant of fermentation broth after $24 \mathrm{~h}$ according to the linear relationship between $\mathrm{HC}$ value and content of commercial cellulase $(2.4 \mathrm{U} / \mathrm{g})$, which were significantly higher than that of commercial cellulose. The method for quantitatively analyzing the detected enzymic production of the strains according to the standard curve of known enzyme is more intuitive, faster, and more effective, which will provide a new idea for the method of measuring enzymic activity of cellulolytic strains. 


\subsection{Screening of the safe cellulolytic marine bacteria for $L$. vannamei aquaculture}

For the aquaculture of $L$. vannamei, the use of probiotics as a group of live bacteria that added directly to water has beneficial effects on organisms in culture, such as water bioremediation, improvement of digestion, intensification of the immune response, and inhibition of the growth of pathogenic bacteria [61]. FAO has suggested the use of probiotics as a major means for the improvement of aquatic environmental quality [62]. People usually use probiotics to replace antibiotics in the process of aquaculture of aquatic animals, which can not only restrain the multiplying of pathogen and enhance the immunity of cultured animals, but also improve the aquaculture environment. However, there is no report about the cellulolytic probiotics from the tropical marine environment in Hainan. Therefore, the indigenous cellulolytic probiotics from the Hainan tropical aquaculture system and the marine environment of SCS that are beneficial for $L$. vannamei aquaculture will not only ensure the safety and improve the production of white shrimp, but also reduce the cost of aquaculture by using the cheap SB as the only carbon source.

\subsubsection{Safety of cellulolytic marine bacteria to $L$. vannamei}

In order to be considered as a probiotic, the strain has to be non-toxic to the host. 26-test cellulolytic marine bacteria were safe for $L$. vanname (Table 3 ), which were agreed with the earlier reports where no mortality has been detected by Macrobrachium rosenbergii and L. vannamei with L. pentosus $[45,63]$. In aquaculture water, the changes of salinity will affect the physiological function of microorganisms, which will eventually hinder their growth, survival, and food consumption [64]. In the present study, we also detected the salinity tolerance and pH tolerance of these 26 cellulolytic marine bacterial strains (data not shown). There were 11 strains suitable for fresh water (0\%o-10\%o) (CFW-C6, CFW-C18, SBC-C23, MW-C44, MW-C79, MW-M10, MW-M13, MW-M14, MW-M15, MWM19, and MW-M20) and 11 strains suitable for aquaculture water (15\%o-30\%o) (CFW-C7, CFW-C32, MW-C42, MW-C45, MW-C52, MW-C61, MW-C77, MW-C81, MW-M5, MW-M9, and MW-M17). MW-C58 was suitable for high salinity environment (15\%o-30\%o), while MW-C48, MW-C63, and MW-M4 were identified as halophilic strains. In addition, all of these bacteria can't grow under over-acidification condition $(\mathrm{pH}<4)$, while some strains can grow under alkaline condition $(\mathrm{pH} 10)$. There were 13 strains with a wide range of acid-alkali resistance. These results will provide important information for the adaptation of these cellulolytic marine bacteria to industrial aquaculture applications.

\subsubsection{Antibiotic susceptibility assay}

In addition to the detection of animal safety, antibiotic susceptibility analysis is also an effective method for identifying potential probiotics. The abuse of antibiotics will destroy the balance of the original microbial flora in the breeding environment, resulting in drug resistance. At the present study, the main purpose was to screen the highly safe strains with low drug resistance. Most test cellulolytic marine bacteria were susceptible to chloramphenicol. Chloramphenicol is a broad-spectrum antibiotic, which has a strong inhibitory effect on Grampositive and Gram-negative bacteria (Goldfarb, Doi, Rodriguez, 1981), and has been used in aquaculture industry since 1980s (Cravedi, Choubert, Delous, 1987; Reide, Siegmund, 1989; Rijkers, Teunissen, Van Oosterom, Van Muiswinkel, 1980). According to our results, the animals in the study environments had been threatened by penicillin, piperacillin, carbenicillin, cefalexin, streptomycin, spectinomycin, tetracycline, erythromycin, and azithromycin, while some antibiotics with relatively lower MAR index could be reasonably used in these environments, such as cefoxitin, ceftriaxone, chloramphenicol, and furazolidone. More importantly, Vibrio sp. WMM19 displayed a lowest MAR index (0.1), which was resistant to only three antibiotics, indicating that this strain 
was safe and non-drug resistance for further use. Of course, antibiotic resistance pattern may vary depending on the geographical locations and selective pressure and these patterns change rapidly from time to time [65].

\subsection{Determination of the SB decomposition of the safe cellulolytic bacteria}

Although high-density aquaculture can bring high profits, the accumulation of high-protein bait and excrement will aggravate the deterioration of the aquaculture water [4]. Residual bait and feces are the main sources of nitrogen and phosphorus during the pressing of aquaculture, while the relative lack of carbon will lead to water deterioration $[3,11-14]$. However, the high cost of adding carbon source artificially limits its application of largescale popularization. Therefore, it has become a research hotspot to find cheap carbon sources. Sugarcane, a tropical crop, requires special environment, such as, an optimum high temperature, availability of sunshine and higher rainfall for its growth. The extraction of juice from sugarcane generates a fibrous residue, SB. Normally one ton of sugarcane produces $280 \mathrm{~kg}$ of SB [66]. SB is rich in fermentable components and usually composed of $25 \%$ lignin, $25 \%$ hemicelluloses and $50 \%$ cellulose [66, 67]. Sugarcane is a widely grown sugar crop in Hainan, China, and its SB is the main wastes of sugar industry. However, there were few reports on SB decomposition of cellulolytic marine bacterial strains in shrimp aquaculture. The cellulase producing strains from seagrass beds of mangrove displayed relatively higher SBase, such as MW-M19 $(4.14 \mathrm{U} / \mathrm{mL})$ and $\mathrm{MW}-\mathrm{C} 77(3.746 \mathrm{U} / \mathrm{mL})$, we reasoned that the cellulolytic bacteria isolated from the seagrass beds in Wenchang could induce the production of cellulase with high enzyme activity by SB, further indicating that it will be more instructive for shrimp aquaculture to isolate cellulolytic strains from the environment similar to the culture environment. Generally, the larger the contact area of SB with microorganisms, the more easily the SB can be degraded into available carbon sources by microorganisms, which can promote the growth of microorganisms and improve water quality.

CFW-C18 and MW-M15 showed the excellent SB decomposition capabilities, and the SB decomposition rates of both were up to $63.81 \%$ and $48.57 \%$, respectively. Interestingly, MW-M19 with lowest MAR Index and highest SBase also displayed the relatively high SB decomposition rate (up to $29.52 \%$ ). Overall, CFW-C18 and MW-M19 with relatively high SBase and SB decomposition rate were obtained in this study, which will lay a foundation for the development of cellulase producing marine microbial agents for $L$. vannamei aquaculture based on the artificial addition of SB as the carbon source.

\section{Conclusions}

In conclusion, we reported the cellulolytic marine bacteria from the tropical marine environment in SCS. Seagrass bed was an important place for screening the cellulolytic bacteria, and the Bacillus and Vibrio were dominant cellulolytic bacteria in seagrass ecosystems. We successfully obtained the safe cellulolytic bacteria with high hydrolysis capacity and definite antibiotic resistance profile, such as MW-M19 with lowest MAR Index and highest SBase, and CFW-C18 and MW-M15 with relatively higher SB decomposition rate, which will make them proficient candidates for $L$. vannamei aquaculture based on low-cost external carbon sources, and even for other biotechnological applications.

\section{Materials And Methods}

\subsection{Description of sampling sites and sample collection}


The shrimp samples and the water samples were extracted by digging $0.5 \mathrm{~m}$ deep around $1 \mathrm{~m}$ away from aerator of the aquaculture ponds, and the muddy sediment samples were collected around $3 \mathrm{~cm}$ away from seagrass. All of the samples were from four sites: shrimp cultural base in Haiwei Town, Changjiang Li Autonomous County $\left(19^{\circ} 26^{\prime} 39.02^{\prime \prime} \mathrm{N}, 108^{\circ} 50^{\prime} 11.23^{\prime \prime} \mathrm{E}\right)$, shrimp cultural base in Huiwen Town, Wenchang City $\left(19^{\circ} 27^{\prime} 28^{\prime \prime} \mathrm{N}, 110^{\circ} 45^{\prime} 13^{\prime \prime} \mathrm{E}\right)$, seagrass beds around mangrove in Huiwen Town, Wenchang City (19 $\left.28^{\prime} 11.66^{\prime \prime} \mathrm{N}, 110^{\circ} 47^{\prime} 41.22^{\prime \prime} \mathrm{E}\right)$, and seagrass beds in Dongjiao Coconut Forest, Huiwen Town, Wenchang City (19³1'28.81"N, 11052'0.45"E). The shrimp samples and the mud samples were putted in the sterile zipper plastic bags, and the water samples were stored in the sterile sampling bottles. All of the samples were stored at $4^{\circ} \mathrm{C}$ for further use.

\subsection{Isolation and purification of marine bacteria}

The samples were serially diluted with sterile normal saline solution $(0.85 \% \mathrm{NaCl})$ within $24 \mathrm{~h}$ of collection to obtain 1:10, 1:10, 1:100, and 1:1,000 dilutions. One hundred microlitres of each diluted sample was spread-plated on marine $2216 \mathrm{E}$ agar and incubated at $30^{\circ} \mathrm{C}$ for $18 \mathrm{~h}$. The agar plates were investigated in terms of colony morphology including shape, margin, elevation and pigmentation. Morphologically dissimilar colonies were selected and streak plated on marine 2216 E agar to obtain pure colonies.

\subsection{Screening and identification of cellulolytic bacteria}

Screening of the cellulolytic bacteria was conducted by carboxymethylcellulose (CMC) agar plates and Congo red staining method. Two microlitres of overnight growth culture in the marine $2216 \mathrm{E}$ of each bacterial isolate was spot plated on $\mathrm{CMC}$ agar $\left(0.2 \% \mathrm{NaCl}, 0.5 \% \mathrm{CMC}\right.$ sodium salt, $0.67 \% \mathrm{Na}_{2} \mathrm{HPO}_{4}, 0.13 \%\left(\mathrm{NH}_{4}\right)_{2} \mathrm{SO}_{4}, 0.05 \%$ $\mathrm{MgSO}_{4} \cdot 7 \mathrm{H}_{2} \mathrm{O}$, and $1.7 \%$ agar). The agar plates were incubated at $30^{\circ} \mathrm{C}$ for $96 \mathrm{~h}$ and then flooded with $1 \mathrm{mg} / \mathrm{mL}$ Congo red for $30 \mathrm{~min}$ at room temperature. The cellulolytic isolates were detected by the cellulolytic zone around the colonies after Congo red staining. The $\mathrm{HC}$ value determined the cellulolytic activity was calculated from the ratio between the diameter of the cellulolytic zone and the diameter of the bacterial colony. In this study, we only selected colonies with a ratio greater than 1 . The selected cellulolytic isolate was identified by molecular genetic analysis. The PCR amplification and 16S rDNA sequence analysis were previously described [44] using a set of primers as follows: forward primer 27F: GAGTTTGATCATGGCTCAG and reverse primer 1492R: CGGTTACCTTGTTACGACTT. All molecular genetic analyses including PCR amplification, 16S rDNA sequence analysis, and homology similarity analysis were carried out by Guangzhou Sangon Biotech Co., Ltd., Guangzhou, China.

\subsection{Cellulolytic activity assay}

The selected isolate was grown in $\mathrm{CMC}$ broth $(0.2 \% \mathrm{NaCl}, 0.5 \% \mathrm{CMC}$ sodium salt, $0.5 \%$ tryptone, and $0.1 \%$ yeast extract) at $30^{\circ} \mathrm{C}$ for $24 \mathrm{~h}$. Bacterial cells were removed from the culture broth by centrifugation at 5,000 rpm for 15 $\min$ at $4^{\circ} \mathrm{C}$. The cell-free supernatant obtained after centrifugation served as a crude enzyme solution, which was analyzed for cellulolytic activity assay.

Herein, filter paper activity (FPase) was used to estimate the cellulolytic activity and concentrations of the produced reducing sugars were estimated by the dinitrosalicylicacid (DNS) method using glucose as the standard. Briefly, cellulolytic activity was measured by incubating $0.5 \mathrm{~mL}$ of enzyme solution with $1 \mathrm{~mL}$ of substrate solution (a $1 \times 6 \mathrm{~cm}$ strip of Whatman No.1 filter paper immersed in $1.0 \mathrm{~mL}$ of $100 \mathrm{mM}$ sodium acetate buffer, $\mathrm{pH} 4.8$ ) at $50^{\circ} \mathrm{C}$ for $30 \mathrm{~min}$. The reducing sugars liberated were determined by the 3,5-dinitrosalicylicacid (DNS) method. The enzyme reaction was terminated by adding $3.0 \mathrm{~mL}$ of DNS reagent and then boiled for $5 \mathrm{~min}$. The solution was 
completely cooled and the optical density of the reaction mixture was measured at $540 \mathrm{~nm}$. In order to evaluate the hydrolytic activity of cellulase on SB (SBase), only filter paper was replaced by SB powder as the substrate, and the other operations were the same. One unit of FPase or SBase was the quantity of enzymes which produced $1 \mu \mathrm{mol}$ of glucose or reducing sugar per minute under the specified conditions. All experiments of cellulolytic activity assay were performed in three replications and the results were reported as mean \pm SD.

\subsection{Safety of cellulolytic marine bacterial strains to L. vannamei}

Before experiments, juvenile L. vannamei were acclimatized for two months with continuous water exchange and constant aeration. The temperature and salinity were maintained at $28^{\circ} \mathrm{C}$ and $25 \%$ o. The shrimps were fed with commercial pellets. Aeration was stopped for about 45 min during feeding, then feces and feed residues at the bottom were removed. Only $20 \%$ of the rearing water in each tank was replaced daily, and unhealthy or injured shrimps were removed. After the acclimation period, shrimps were randomly divided into 87 tanks (5-L), each containing 10 shrimps. The shrimps in each tank were not fed for one day, and unhealthy or injured shrimps were removed. Finally, ensure that the number of shrimps in each tank was 10 by constantly replenishing healthy shrimp. During experiments, the temperature and salinity remained constant without replacing water.

The safety of the cellulolytic marine bacterial strains was tested by subjecting healthy shrimps to immersion challenge. The safety experiment for each strain was divided into two experimental groups, each having three replicates. The experimental group was immersed in suspension of final concentration of about $10^{7} \mathrm{CFU} \mathrm{mL}^{-1}$ of rearing water, while the control group was immersed with rearing water without bacteria. All of the shrimps were fed basal diet and the mortality was monitored daily for one week.

\subsection{Antibiotic susceptibility test}

Antibiotic susceptibility tests were conducted by the disc diffusion method. The tests were done by spreading 0.1 $\mathrm{mL}$ of 18-h-old broth culture of the test strains on marine $2216 \mathrm{E}$ agar plates and then placing antibiotics susceptibility discs (Wenzhou Kangtai Biotechnology Co., Ltd., Wenzhou, China) on the plates. Growth-inhibition zones around the discs were measured after incubation at $30^{\circ} \mathrm{C}$ for $19 \mathrm{~h}$. In this experiment, 30 kinds of antibiotics belonging to 10 classifies of antibiotics susceptibility discs were selected for antibiotic sensitivity test with three replications (Table S1).

Multiple antibiotic resistance (MAR) index of present isolates against the tested antibiotics was calculated based on the following formula [68]:

MAR Index $=X /(Y \times Z)$; where: $X=$ Total cases of antibiotic resistance; $Y=$ Total number of antibiotics used in the study; $Z$ = Total number of isolates. A MAR Index value of equal or less than 0.2 was defined as antibiotics that were seldom or never used.

\subsection{SB decomposition of cellulolytic marine bacterial strains}

The cellulolytic marine bacterial strains were incubated in SB broth ( $\mathrm{g} / \mathrm{L}$ ) containing $10 \mathrm{NaCl}, 4 \mathrm{SB}$ powder, 0.24 $\mathrm{MgSO}_{4}, 0.011 \mathrm{CaCl}_{2}, 6.78 \mathrm{Na}_{2} \mathrm{HPO}_{4}, 3 \mathrm{KH}_{2} \mathrm{PO}_{4}$, and $1 \mathrm{NH}_{4} \mathrm{C}$ at $30^{\circ} \mathrm{C}$ for 15 days. The culture was filtered by sterilized neutral detergent ( $\mathrm{g} / \mathrm{L}$ ) containing 37.2 EDTA, 13.6 sodium perborate, $30 \mathrm{SDS}, 10$ glycol ether (mL/L), and $23 \mathrm{Na}_{2} \mathrm{HPO}_{4}$, and then washed by ethanol. The remaining SB (dry weight) in the culture was used to measure the rate of SB decomposition. 


\section{Abbreviations}

SB: sugarcane bagasse; HC: hydrolysis capacity; MAR Index: multiple antibiotic resistance index; FPase: filter paper activity; SBase: SB enzyme activity; CMC: carboxymethylcellulose; DNS: 3,5-dinitrosalicylic acid; SCS: South China Sea; REC: relative enzyme content; L. vannamei: Litopenaeus vannamei; L. pentosus: Lactobacillus pentosus, Trichoderma harzianum: T. harzianum.

\section{Declarations}

\section{Authors' contributions}

Wei Ren, Xueni Xu, and Zhenyu Xie designed the experiments. Wei Ren and Xueni Xu performed the experiments. Wei Ren, Xueni Xu, Hao Long, Xiang Zhang, Xiaoni Cai, and Aiyou Huang analyzed the data. Zhenyu Xie supervised the study and reviewed the manuscript. Wei Ren wrote the manuscript. All authors have read and approved the final manuscript.

\section{Author details}

${ }^{1}$ State Key Laboratory of Marine Resource Utilization in the South China Sea, Hainan University, Haikou, 570228, Hainan Province, China. ${ }^{2}$ Hainan Provincial Key Laboratory for Tropical Hydrobiology and Biotechnology, Hainan University, Haikou, 570228, Hainan Province, China. ${ }^{3}$ College of Marine Sciences, Hainan University, Haikou, 570228, Hainan Province, China. ${ }^{a}$ The first two authors contributed equally to this work.

\section{Acknowledgements}

Not applicable.

\section{Competing interests}

The authors declare that they have no known competing financial interests or personal relationships that could have appeared to influence the work reported in this paper.

\section{Availability of data and materials}

All data generated or analyzed during this study are included in this published article and its supplementary information files.

\section{Ethics approval and consent to participate}

Not applicable.

\section{Consent for publication}

Not applicable.

\section{Funding}

This study was supported by the Marine Economic and Innovative Demonstration City Project of State Oceanic Administration (HHCL201802 and HHCL201813), the Foundation of Hainan Agricultural and Rural Department 
(NY-2019-819), the National Natural Science Foundation of China (41466002, 31660744), and the Scientific Research Foundation of Hainan University (KYQD(ZR)1967, KYQD(ZR)1819, KYQD(ZR)20060)

\section{Publisher's Note}

Springer Nature remains neutral with regard to jurisdictional claims in published maps and institutional affiliations.

\section{References}

1. Huang M, Xie J, Yu Q, Xu C, Zhou L, Qin JG, Chen L, Li E: Toxic effect of chronic nitrite exposure on growth and health in Pacific white shrimp Litopenaeus vannamei. Aquaculture 2020:735664.

2. Liu CH, Chiu CS, Ho PL, Wang SW: Improvement in the growth performance of white shrimp, Litopenaeus vannamei, by a protease-producing probiotic, Bacillus subtilis E20, from natto. Journal of Applied Microbiology 2009, 107:1031-1041.

3. Hoang MN, Nguyen PN, Bossier P: Water quality, animal performance, nutrient budgets and microbial community in the biofloc-based polyculture system of white shrimp, Litopenaeus vannamei and gray mullet, Mugil cephalus. Aquaculture 2020, 515.

4. Li Y, Wang L, Yan Z, Chao C, Yu H, Yu D, Liu C: Effectiveness of dredging on internal phosphorus loading in a typical aquacultural lake. The Science of the total environment 2020, 744:140883-140883.

5. Kuhn DD, Smith SA, Boardman GD, Angier MW, Marsh L, Flick GJ, Jr.: Chronic toxicity of nitrate to Pacific white shrimp, Litopenaeus vannamei: Impacts on survival, growth, antennae length, and pathology. Aquaculture 2010, 309:109-114.

6. Guo H, Xian J-A, Wang AL: Analysis of digital gene expression profiling in hemocytes of white shrimp Litopenaeus vannamei under nitrite stress. Fish \& Shellfish Immunology 2016, 56:1-11.

7. Chai ZY, Wang H, Deng Y, Hu Z, Tang YZ: Harmful algal blooms significantly reduce the resource use efficiency in a coastal plankton community. Science of the Total Environment 2020, 704.

8. Bachere E: Shrimp immunity and disease control - Introduction. Aquaculture 2000, 191:3-11.

9. Paez-Osuna F: The environmental impact of shrimp aquaculture: Causes, effects, and mitigating alternatives. Environmental Management 2001, 28:131-140.

10. Hatje V, de Souza MM, Ribeiro LF, Eca GF, Barros F: Detection of environmental impacts of shrimp farming through multiple lines of evidence. Environmental Pollution 2016, 219:672-684.

11. Mariane de Morais AP, Abreu PC, Wasielesky W, Krummenauer D: Effect of aeration intensity on the biofilm nitrification process during the production of the white shrimp Litopenaeus vannamei (Boone, 1931) in Biofloc and clear water systems. Aquaculture 2020, 514.

12. Lin YC, Chen JC: Acute toxicity of ammonia on Litopenaeus vannamei Boone juveniles at different salinity levels. Journal of Experimental Marine Biology \& Ecology 2001, 259:109-119.

13. Lin Y-C, Chen J-C: Acute toxicity of nitrite on Litopenaeus vannamei (Boone) juveniles at different salinity levels. Aquaculture 2003, 224:193-201.

14. Penalosa-Martinell D, Vela-Magana M, Ponce-Diaz G, Araneda Padilla ME: Probiotics as environmental performance enhancers in the production of white shrimp (Penaeus vannamei) larvae. Aquaculture 2020, 514. 
15. Robertson LA, Vanniel EWJ, Torremans RAM, Kuenen JG: Simultaneous nitrification and denitrification in aerobic chemostat cultures of Thiosphaera pantotropha. Applied and Environmental Microbiology 1988, 54:2812-2818.

16. Kesarcodi-Watson A, Kaspar H, Lategan MJ, Gibson L: Probiotics in aquaculture: the need, principles and mechanisms of action and screening processes. Aquaculture 2008, 274:1-14.

17. Poli MA, Legarda EC, de Lorenzo MA, Martins MA, do Nascimento Vieira F: Pacific white shrimp and Nile tilapia integrated in a biofloc system under different fish-stocking densities. Aquaculture 2019, 498:83-89.

18. Azim ME, Little DC: The biofloc technology (BFT) in indoor tanks: water quality, biofloc composition, and growth and welfare of Nile tilapia (Oreochromis niloticus). Aquaculture 2008, 283:29-35.

19. Hisano H, Barbosa PT, Hayd LA, Mattioli CC: Evaluation of Nile tilapia in monoculture and polyculture with giant freshwater prawn in biofloc technology system and in recirculation aquaculture system. International Aquatic Research 2019, 11:335-346.

20. Avnimelech Y: Carbon nitrogen ratio as a control element in aquaculture systems. Aquaculture 1999, 176:227235.

21. Burford MA, Thompson PJ, Mclntosh RP, Bauman RH, Pearson DC: The contribution of flocculated material to shrimp (Litopenaeus vannamei) nutrition in a high-intensity, zero-exchange system. Aquaculture 2004, 232:525-537.

22. De Schryver P, Crab R, Defoirdt T, Boon N, Verstraete W: The basics of bio-flocs technology: The added value for aquaculture. Aquaculture 2008, 277:125-137.

23. Dawood MAO, Koshio S, Angeles Esteban M: Beneficial roles of feed additives as immunostimulants in aquaculture: a review. Reviews in Aquaculture 2018, 10:950-974.

24. Samocha TM, Patnaik S, Speed M, Ali A-M, Burger JM, Almeida RV, Ayub Z, Harisanto M, Horowitz A, Brock DL: Use of molasses as carbon source in limited discharge nursery and grow-out systems for Litopenaeus vannamei. Aquacultural Engineering 2007, 36:184-191.

25. Grommen R, Van Hauteghem I, Van Wambeke M, Verstraete W: An improved nitrifying enrichment to remove ammonium and nitrite from freshwater aquaria systems. Aquaculture 2002, 211:115-124.

26. Egli T, Quayle JR: Influence of the carbon: nitrogen ratio of the growth medium on the cellular composition and the ability of the methylotrophic yeast Hansenula polymorpha to utilize mixed carbon sources. Journal of General Microbiology 1986, 132:1779-1788.

27. Dong W, Xue M, Zhang Y, Xin F, Wei C, Zhang W, Wu H, Ma J, Jiang M: Characterization of a $\beta$-glucosidase from Paenibacillus species and its application for succinic acid production from sugarcane bagasse hydrolysate. Bioresource technology 2017, 241:309-316.

28. Xu C, Zhang J, Zhang Y, Guo Y, Xu H, Xu J, Wang Z: Enhancement of high-solids enzymatic hydrolysis efficiency of alkali pretreated sugarcane bagasse at low cellulase dosage by fed-batch strategy based on optimized accessory enzymes and additives. Bioresource Technology 2019, 292:121993.

29. Liu W, Tanimura A, Nagara Y, Watanabe T, Maegawa S, Toyohara H: Wetland environmental bioreactor system contributes to the decomposition of cellulose. Ecology and evolution 2019, 9:8013-8024.

30. Wang H, Zhai L, Geng A: Enhanced cellulase and reducing sugar production by a new mutant strain Trichoderma harzianum EUA20. Journal of bioscience and bioengineering 2020, 129:242-249.

31. Hu J, Xue Y, Guo H, Gao M-t, Li J, Zhang S, Tsang YF: Design and composition of synthetic fungal-bacterial microbial consortia that improve lignocellulolytic enzyme activity. Bioresource Technology 2017, 227:247-255. 
32. Harms H, Schlosser D, Wick LY: Untapped potential: exploiting fungi in bioremediation of hazardous chemicals. Nature Reviews Microbiology 2011, 9:177-192.

33. Trincone A: Enzymatic processes in marine biotechnology. Marine drugs 2017, 15:93.

34. Ren W, Liu L, Gu L, Yan W, Feng YI, Dong D, Wang S, Lyu M, Wang C: Crystal Structure of GH49 Dextranase from Arthrobacter oxidans KQ11: Identification of Catalytic Base and Improvement of Thermostability Using Semirational Design Based on B-Factors. Journal of Agricultural and Food Chemistry 2019, 67:4355-4366.

35. Ren W, Cai R, Yan W, Lyu M, Fang Y, Wang S: Purification and characterization of a biofilm-degradable dextranase from a marine bacterium. Marine drugs 2018, 16:51.

36. Ren W, Ding Y, Gu L, Yan W, Wang C, Lyu M, Wang C, Wang S: Characterization and mechanism of the effects of $\mathrm{Mg}$-Fe layered double hydroxide nanoparticles on a marine bacterium: new insights from genomic and transcriptional analyses. Biotechnology for biofuels 2019, 12:196.

37. do Espirito Santo CM, Pinheiro IC, Alves de Jesus GF, Pedreira Mourino JL, Vieira FdN, Seiffert WQ: Soybean molasses as an organic carbon source in the farming of Litopenaeus vannamei (Boone, 1931) in a biofloc system. Aquaculture Research 2017, 48:1827-1835.

38. da Silva BC, Vieira FdN, Pedreira Mourino JL, Ferreira GS, Seiffert WQ: Salts of organic acids selection by multiple characteristics for marine shrimp nutrition. Aquaculture 2013, 384:104-110.

39. Xu D, Li R, Hu C, Sun P, Jiao N, Warren A: Microbial eukaryote diversity and activity in the water column of the South China Sea based on DNA and RNA high throughput sequencing. Frontiers in microbiology 2017, 8:1121.

40. Pendleton L, Donato DC, Murray BC, Crooks S, Jenkins WA, Sifleet S, Craft C, Fourqurean JW, Kauffman JB, Marbà N: Estimating global "blue carbon" emissions from conversion and degradation of vegetated coastal ecosystems. PloS one 2012, 7:e43542.

41. Gullström M, Lyimo LD, Dahl M, Samuelsson GS, Eggertsen M, Anderberg E, Rasmusson LM, Linderholm HW, Knudby A, Bandeira S: Blue carbon storage in tropical seagrass meadows relates to carbonate stock dynamics, plant-sediment processes, and landscape context: insights from the western Indian Ocean. Ecosystems 2018, 21:551-566.

42. Lavery PS, Mateo M-Á, Serrano O, Rozaimi M: Variability in the carbon storage of seagrass habitats and its implications for global estimates of blue carbon ecosystem service. PloS one 2013, 8:e73748.

43. Behera B, Parida S, Dutta S, Thatoi H: Isolation and identification of cellulose degrading bacteria from mangrove soil of Mahanadi river delta and their cellulase production ability. American journal of microbiological research 2014, 2:41-46.

44. Chantarasiri A: Aquatic Bacillus cereus JD0404 isolated from the muddy sediments of mangrove swamps in Thailand and characterization of its cellulolytic activity. The Egyptian Journal of Aquatic Research 2015, 41:257-264.

45. Zheng CN, Wang W: Effects of Lactobacillus pentosus on the growth performance, digestive enzyme and disease resistance of white shrimp, Litopenaeus vannamei (Boone, 1931). Aquaculture Research 2017, 48:2767-2777.

46. Priya I, Dhar M, Bajaj B, Koul S, Vakhlu J: Cellulolytic activity of thermophilic bacilli isolated from Tattapani hot spring sediment in North West Himalayas. Indian journal of microbiology 2016, 56:228-231.

47. Patel AK, Singhania RR, Sim SJ, Pandey A: Thermostable cellulases: current status and perspectives. Bioresource technology 2019, 279:385-392. 
48. Kang S, Park Y, Lee J, Hong S, Kim SW: Production of cellulases and hemicellulases by Aspergillus niger KK2 from lignocellulosic biomass. Bioresource technology 2004, 91:153-156.

49. Mohapatra S, Padhy S, Mohapatra PKD, Thatoi H: Enhanced reducing sugar production by saccharification of lignocellulosic biomass, Pennisetum species through cellulase from a newly isolated Aspergillus fumigatus. Bioresource technology 2018, 253:262-272.

50. Han X, Song W, Liu G, Li Z, Yang P, Qu Y: Improving cellulase productivity of Penicillium oxalicum RE-10 by repeated fed-batch fermentation strategy. Bioresource technology 2017, 227:155-163.

51. Cheng Y, Song X, Qin Y, Qu Y: Genome shuffling improves production of cellulase by Penicillium decumbens JU-A10. Journal of applied microbiology 2009, 107:1837-1846.

52. Wang Z, Ong HX, Geng A: Cellulase production and oil palm empty fruit bunch saccharification by a new isolate of Trichoderma koningii D-64. Process Biochemistry 2012, 47:1564-1571.

53. Wang Z, Bay H, Chew K, Geng A: High-loading oil palm empty fruit bunch saccharification using cellulases from Trichoderma koningii MF6. Process Biochemistry 2014, 49:673-680.

54. Jiang X, Geng A, He N, Li Q: New isolate of Trichoderma viride strain for enhanced cellulolytic enzyme complex production. Journal of bioscience and bioengineering 2011, 111:121-127.

55. Fang X, Yano S, Inoue H, Sawayama S: Strain improvement of Acremonium cellulolyticus for cellulase production by mutation. Journal of Bioscience and Bioengineering 2009, 107:256-261.

56. Liao G-Y, Zhao S, Zhang T, Li C-X, Liao L-S, Zhang F-F, Luo X-M, Feng J-X: The transcription factor TpRfx 1 is an essential regulator of amylase and cellulase gene expression in Talaromyces pinophilus. Biotechnology for biofuels 2018, 11:276.

57. Okuda N, Fujii T, Inoue H, Ishikawa K, Hoshino T: Enhancing cellulase production by overexpression of xylanase regulator protein gene, $x \ln R$, in Talaromyces cellulolyticus cellulase hyperproducing mutant strain. Bioscience, Biotechnology, and Biochemistry 2016, 80:2065-2068.

58. Saini A, Aggarwal NK, Yadav A: Isolation and screening of cellulose hydrolyzing bacteria from different ecological niches. Bioengineering and Bioscience 2017, 5:7-13.

59. Lu W-J, Wang H-T, Yang S-J, Wang Z-C, Nie Y-F: Isolation and characterization of mesophilic cellulosedegrading bacteria from flower stalks-vegetable waste co-composting system. The Journal of general and applied microbiology 2005, 51:353-360.

60. Khianngam S, Pootaeng-on Y, Techakriengkrai T, Tanasupawat S: Screening and identification of cellulase producing bacteria isolated from oil palm meal. Journal of Applied Pharmaceutical Science 2014, 4:90.

61. Peñalosa-Martinell D, Vela-Magaña M, Ponce-Díaz G, Padilla MEA: Probiotics as environmental performance enhancers in the production of white shrimp (Penaeus vannamei) larvae. Aquaculture 2020, 514:734491.

62. Subasinghe RP, Curry D, McGladdery SE, Bartley D: Recent technological innovations in aquaculture. Review of the State of World Aquaculture FAO Fish Circ 2003, 886:59-74.

63. Dash G, Raman RP, Prasad KP, Makesh M, Pradeep M, Sen S: Evaluation of Lactobacillus plantarum as feed supplement on host associated microflora, growth, feed efficiency, carcass biochemical composition and immune response of giant freshwater prawn, Macrobrachium rosenbergii (de Man, 1879). Aquaculture 2014, 432:225-236.

64. Jaffer Y, Saraswathy R, Ishfaq M, Antony J, Bundela D, Sharma P: Effect of low salinity on the growth and survival of juvenile pacific white shrimp, Penaeus vannamei: A revival. Aquaculture 2020, 515:734561. 
65. Kathleen MM, Samuel L, Felecia C, Reagan EL, Kasing A, Lesley M, Toh SC: Antibiotic Resistance of Diverse Bacteria from Aquaculture in Borneo. International journal of microbiology 2016, 2016:2164761-2164761.

66. Soccol CR, de Souza Vandenberghe LP, Pedroni Medeiros AB, Karp SG, Buckeridge M, Ramos LP, Pitarelo AP, Ferreira-Leitao V, Fortes Gottschalk LM, Ferrara MA, et al: Bioethanol from lignocelluloses: Status and perspectives in Brazil. Bioresource Technology 2010, 101:4820-4825.

67. Ejaz U, Muhammad S, Ali FI, Hashmi IA, Sohail M: Methyltrioctylammonium chloride mediated removal of lignin from sugarcane bagasse for themostable cellulase production. International Journal of Biological Macromolecules 2019, 140:1064-1072.

68. Najiah M, Lee S, Wendy W, Tee L, Nadirah M, Faizah S: Antibiotic resistance and heavy metals tolerance in gram-negative bacteria from diseased American bullfrog (Rana catesbeiana) cultured in Malaysia. Agricultural Sciences in China 2009, 8:1270-1275.

\section{Tables}

Table 1. Marine bacterial strains isolated from four sites.

\begin{tabular}{|c|c|c|c|c|}
\hline & Sampling site & Sample type & $\begin{array}{l}\text { Total number of } \\
\text { bacteria }\end{array}$ & $\begin{array}{l}\text { Number of } \\
\text { bacteria with } \\
\mathrm{HC}\end{array}$ \\
\hline \multirow[t]{2}{*}{ Aquaculture } & $\begin{array}{l}\text { shrimp cultural base in Haiwei } \\
\text { Town }\end{array}$ & $\begin{array}{l}\text { Shrimp, water, } \\
\text { mud }\end{array}$ & 335 & 4 \\
\hline & $\begin{array}{l}\text { shrimp cultural base in Huiwen } \\
\text { Town }\end{array}$ & $\begin{array}{l}\text { Shrimp, water, } \\
\text { mud }\end{array}$ & 658 & 2 \\
\hline \multirow[t]{2}{*}{ Nature } & Mangrove in Huiwen Town & mud & 1202 & 58 \\
\hline & $\begin{array}{l}\text { Dongjiao Coconut Forest in } \\
\text { Huiwen Town }\end{array}$ & mud & 390 & 33 \\
\hline
\end{tabular}

Note: the natural environments include the seagrass beds of Mangrove and Dongjiao Coconut Forest in Huiwen Town; aquaculture environments include two shrimp cultural bases in Haiwei Town and Huiwen Town.

Table 2. Fpase, relative enzyme content (REC), and hydrolysis capacity (HC) values of 58 cellulolytic bacteria. 


\begin{tabular}{|c|c|c|c|c|c|c|}
\hline \multicolumn{3}{|c|}{ Isolates code and species } & \multirow{2}{*}{$\begin{array}{l}\text { Site } \\
\text { D }\end{array}$} & \multirow{2}{*}{$\begin{array}{l}\text { Fpase }(\mathrm{U} / \mathrm{mL}) \\
0.017 \pm 0.078\end{array}$} & \multirow{2}{*}{$\begin{array}{l}\operatorname{REC}(\mathrm{U} / \mathrm{g}) \\
2.680 \pm 0.032\end{array}$} & \multirow{2}{*}{$\begin{array}{l}\text { HC value } \\
1.090 \pm 0.038\end{array}$} \\
\hline 1 & MW-C2 & Bacillus aquimaris & & & & \\
\hline 2 & MW-C3 & Microbulbifersp. & $\mathrm{D}$ & $0.090 \pm 0.104$ & $3.107 \pm 0.030$ & $1.919 \pm 0.171$ \\
\hline 3 & MW-C4 & Microbulbifersp. & $\mathrm{D}$ & $0.196 \pm 0.244$ & $3.077 \pm 0.017$ & $1.762 \pm 0.056$ \\
\hline 4 & CFW-C5 & Bacillus sp. & D & $0.017 \pm 0.078$ & $3.046 \pm 0.010$ & $1.672 \pm 0.024$ \\
\hline 5 & CFW-C6 & Bacillus safensis sp. & D & $0.288 \pm 0.097$ & $3.138 \pm 0.004$ & $2.187 \pm 0.090$ \\
\hline 6 & CFW-C7 & Bacillus subtilis & D & $0.342 \pm 0.056$ & $3.138 \pm 0.002$ & $2.138 \pm 0.098$ \\
\hline 7 & CFW-C8 & Bacillus sp. & $\mathrm{D}$ & $0.017 \pm 0.078$ & $3.117 \pm 0.005$ & $1.913 \pm 0.024$ \\
\hline 8 & CFW-C9 & Bacillus sp. & $\mathrm{D}$ & $0.145 \pm 0.003$ & $3.137 \pm 0.004$ & $2.120 \pm 0.105$ \\
\hline 9 & CFW-C10 & Bacillus cereus & $\mathrm{D}$ & $0.180 \pm 0.231$ & $2.972 \pm 0.024$ & $1.511 \pm 0.046$ \\
\hline 10 & CFW-C18 & Microbulbifersp. & D & $0.329 \pm 0.118$ & $2.996 \pm 0.193$ & $2.439 \pm 0.532$ \\
\hline 11 & SBC-C23 & Bacillus sp. & A & $0.397 \pm 0.047$ & $3.131 \pm 0.008$ & $2.036 \pm 0.114$ \\
\hline 12 & SBC-C26 & Tenacibaculum ascidiaceicola & A & $0.017 \pm 0.078$ & $2.920 \pm 0.020$ & $1.419 \pm 0.033$ \\
\hline 13 & SBC-C30 & Bacillus sp. & A & $0.085 \pm 0.076$ & $2.924 \pm 0.007$ & $1.425 \pm 0.012$ \\
\hline 14 & CFW-C32 & Bacillus pumilus & $\mathrm{D}$ & $0.160 \pm 0.056$ & $3.136 \pm 0.005$ & $2.272 \pm 0.055$ \\
\hline 15 & SBC-C34 & Muricauda sp. & A & $0.327 \pm 0.109$ & $3.068 \pm 0.003$ & $1.733 \pm 0.013$ \\
\hline 16 & SBW-C35 & Bacillus sp. & B & $0.209 \pm 0.144$ & $3.056 \pm 0.005$ & $1.699 \pm 0.103$ \\
\hline 17 & SBW-C40 & Bacillus sp. & B & $0.597 \pm 0.261$ & $3.028 \pm 0.024$ & $1.632 \pm 0.059$ \\
\hline 18 & MW-C41 & Microbulbifer mangrovi & C & $0.250 \pm 0.319$ & $2.858 \pm 0.038$ & $1.323 \pm 0.054$ \\
\hline 19 & MW-C42 & Bacillus paralicheniformis & C & $0.120 \pm 0.084$ & $3.110 \pm 0.014$ & $2.432 \pm 0.071$ \\
\hline 20 & MW-C44 & Bacillus sp. & C & $0.017 \pm 0.078$ & $3.090 \pm 0.016$ & $2.514 \pm 0.058$ \\
\hline 21 & MW-C45 & Bacillus sp. & C & $0.065 \pm 0.069$ & $3.040 \pm 0.023$ & $2.658 \pm 0.058$ \\
\hline 22 & MW-C47 & Bacillus sp. & C & $0.017 \pm 0.078$ & $2.937 \pm 0.045$ & $2.867 \pm 0.076$ \\
\hline 23 & MW-C48 & Vibrio sp. & C & $0.554 \pm 0.176$ & $2.684 \pm 0.101$ & $3.216 \pm 0.119$ \\
\hline 24 & MW-C52 & Bacillus subtilis & C & $0.325 \pm 0.125$ & $3.072 \pm 0.011$ & $2.573 \pm 0.031$ \\
\hline 25 & MW-C54 & Vibrionaceae bacterium & C & $0.060 \pm 0.061$ & $2.961 \pm 0.005$ & $1.490 \pm 0.121$ \\
\hline 26 & MW-C56 & Bacillus altitudinis & C & $0.069 \pm 0.074$ & $2.933 \pm 0.024$ & $1.441 \pm 0.040$ \\
\hline 27 & MW-C57 & Bacillus sp. & C & $2.325 \pm 0.061$ & $3.123 \pm 0.022$ & - \\
\hline 28 & MW-C58 & Microbulbifer mangrovi & C & $0.046 \pm 0.025$ & $3.120 \pm 0.017$ & $2.223 \pm 0.223$ \\
\hline 29 & MW-C59 & Bacillus sp. & C & $0.017 \pm 0.078$ & $3.045 \pm 0.029$ & $1.676 \pm 0.073$ \\
\hline 30 & MW-C60 & Bacillus firmus & C & $0.265 \pm 0.141$ & $3.055 \pm 0.022$ & $1.698 \pm 0.058$ \\
\hline 31 & MW-C61 & Bacillus sp. & C & $0.265 \pm 0.068$ & $2.977 \pm 0.192$ & $2.675 \pm 0.376$ \\
\hline
\end{tabular}




\begin{tabular}{|c|c|c|c|c|c|c|}
\hline 32 & MW-C62 & Bacillus cereus & $\mathrm{C}$ & $0.042 \pm 0.036$ & $2.979 \pm 0.031$ & $1.527 \pm 0.059$ \\
\hline 33 & MW-C63 & Vibrionaceae bacterium & $\mathrm{C}$ & $0.027 \pm 0.015$ & $3.118 \pm 0.017$ & $2.380 \pm 0.098$ \\
\hline 34 & MW-C65 & Microbulbifer mangrovi & $\mathrm{C}$ & $0.132 \pm 0.163$ & $2.933 \pm 0.036$ & $1.443 \pm 0.062$ \\
\hline 35 & MW-C67 & Bacillus cereus & $\mathrm{C}$ & $0.386 \pm 0.204$ & $2.726 \pm 0.008$ & $1.145 \pm 0.010$ \\
\hline 36 & MW-C69 & Vibrionaceae bacterium & C & $0.020 \pm 0.005$ & $2.994 \pm 0.012$ & $1.555 \pm 0.025$ \\
\hline 37 & MW-C71 & Vibrionaceae bacterium & $\mathrm{C}$ & $0.364 \pm 0.077$ & $2.794 \pm 0.048$ & $1.234 \pm 0.062$ \\
\hline 38 & MW-C72 & Microbulbifer taiwanensis & $\mathrm{C}$ & $0.051 \pm 0.049$ & $2.916 \pm 0.020$ & $1.413 \pm 0.033$ \\
\hline 39 & MW-C73 & Bacillus sp. & $\mathrm{C}$ & $0.101 \pm 0.103$ & $3.112 \pm 0.021$ & $1.903 \pm 0.091$ \\
\hline 40 & MW-C74 & Vibrionaceae bacterium & $\mathrm{C}$ & $0.170 \pm 0.193$ & $2.729 \pm 0.081$ & $1.154 \pm 0.098$ \\
\hline 41 & MW-C76 & Microbulbifersp. & $\mathrm{C}$ & $0.017 \pm 0.078$ & $2.964 \pm 0.032$ & $1.498 \pm 0.062$ \\
\hline 42 & MW-C77 & Bacillus altitudinis & $\mathrm{C}$ & $0.128 \pm 0.079$ & $3.034 \pm 0.018$ & $2.675 \pm 0.043$ \\
\hline 43 & MW-C78 & Bacillus sp. & $\mathrm{C}$ & $0.130 \pm 0.125$ & $2.975 \pm 0.063$ & $1.531 \pm 0.132$ \\
\hline 44 & MW-C79 & Bacillus subtilis & $\mathrm{C}$ & $0.195 \pm 0.127$ & $2.550 \pm 0.129$ & $3.361 \pm 0.138$ \\
\hline 45 & MW-C81 & Bacillus subtilis & $\mathrm{C}$ & $0.200 \pm 0.019$ & $3.134 \pm 0.008$ & $2.042 \pm 0.073$ \\
\hline 46 & MW-C83 & Bacillus cereus & C & $0.018 \pm 0.001$ & $3.086 \pm 0.010$ & $1.789 \pm 0.033$ \\
\hline 47 & MW-C86 & Bacillus sp. & $\mathrm{C}$ & $0.077 \pm 0.085$ & $2.637 \pm 0.049$ & $1.043 \pm 0.053$ \\
\hline 48 & MW-C88 & Bacillus sp. & $\mathrm{C}$ & $0.071 \pm 0.039$ & $2.911 \pm 0.023$ & $1.404 \pm 0.037$ \\
\hline 49 & MW-M4 & Bacillus sp. & C & $0.017 \pm 0.078$ & $2.648 \pm 0.043$ & $3.263 \pm 0.048$ \\
\hline 50 & MW-M5 & Exiguobacterium sp. & $\mathrm{C}$ & $0.017 \pm 0.078$ & $1.790 \pm 0.533$ & $3.951 \pm 0.367$ \\
\hline 51 & MW-M9 & Vibrionaceae bacterium & $\mathrm{C}$ & $0.017 \pm 0.078$ & $3.098 \pm 0.017$ & $2.482 \pm 0.065$ \\
\hline 52 & MW-M10 & Bacillus sp. & $\mathrm{C}$ & $0.028 \pm 0.016$ & $1.965 \pm 0.793$ & $3.752 \pm 0.610$ \\
\hline 53 & MW-M13 & Bacillus sp. & $\mathrm{C}$ & $0.049 \pm 0.046$ & $3.104 \pm 0.039$ & $2.323 \pm 0.258$ \\
\hline 54 & MW-M14 & Bacillus cereus & $\mathrm{C}$ & $0.017 \pm 0.078$ & $2.343 \pm 0.445$ & $3.505 \pm 0.406$ \\
\hline 55 & MW-M15 & Bacillus sp. & C & $0.053 \pm 0.051$ & $3.097 \pm 0.047$ & $2.343 \pm 0.276$ \\
\hline 56 & MW-M17 & Bacillus sp. & C & $0.017 \pm 0.078$ & $3.117 \pm 0.026$ & $2.346 \pm 0.164$ \\
\hline 57 & MW-M19 & Vibrio sp. & $\mathrm{C}$ & $0.018 \pm 0.002$ & $3.061 \pm 0.086$ & $2.436 \pm 0.350$ \\
\hline 58 & MW-M20 & Bacillus sp. & C & $0.907 \pm 0.056$ & $2.820 \pm 0.222$ & $2.990 \pm 0.327$ \\
\hline
\end{tabular}

Note: A, B, C, and D represent four sampling sites, shrimp cultural base in Haiwei Town, shrimp cultural base in Huiwen Town, Mangrove in Huiwen Town, and Dongjiao Coconut Forest in Huiwen Town, respectively. The HC values of any isolates less than 1 are not shown, and the REC of those isolates are also not shown.

Table 3. The tests of safety and SB decomposition of 28 cellulolytic marine bacteria. 


\begin{tabular}{|c|c|c|c|c|}
\hline & \multicolumn{2}{|l|}{ Safety test } & \multicolumn{2}{|c|}{ SB decomposition test } \\
\hline & Survival rate (\%) & MAR index & SBase & Decomposition rate (\%) \\
\hline CFW-C18 & $93.33 \pm 11.55$ & 0.47 & $1.04 \pm 0.27$ & $63.81 \pm 2.69$ \\
\hline CFW-C32 & $85.00 \pm 5.00$ & 0.30 & $0.63 \pm 0.24$ & $27.62 \pm 5.39$ \\
\hline CFW-C6 & $96.67 \pm 5.77$ & 0.70 & $1.23 \pm 0.54$ & $13.81 \pm 0.83$ \\
\hline CFW-C7 & $93.33 \pm 5.77$ & 0.70 & $0.12 \pm 0.14$ & $36.47 \pm 1.15$ \\
\hline CFW-C9 & 0.00 & 0.43 & - & - \\
\hline MW-C42 & $100.00 \pm 0.00$ & 0.63 & $0.70 \pm 0.02$ & $35.24 \pm 3.73$ \\
\hline MW-C44 & $90.00 \pm 10.00$ & 0.70 & $2.15 \pm 0.16$ & $2.59 \pm 0.46$ \\
\hline MW-C45 & $90.00 \pm 10.00$ & 0.73 & $0.02 \pm 0.01$ & $29.52 \pm 3.34$ \\
\hline MW-C47 & $3.33 \pm 5.77$ & 0.67 & - & - \\
\hline MW-C48 & $93.33 \pm 5.77$ & 0.93 & $1.44 \pm 1.80$ & $2.59 \pm 0.46$ \\
\hline MW-C52 & $86.67 \pm 5.77$ & 0.83 & $0.02 \pm 0.23$ & $35.23 \pm 3.03$ \\
\hline MW-C58 & $93.33 \pm 5.77$ & 0.73 & $0.55 \pm 0.32$ & $39.05 \pm 0.60$ \\
\hline MW-C61 & $96.67 \pm 5.77$ & 0.87 & $0.12 \pm 0.18$ & 0.00 \\
\hline MW-C63 & $93.33 \pm 5.77$ & 0.70 & $1.90 \pm 0.90$ & $33.33 \pm 3.44$ \\
\hline MW-C77 & $86.87 \pm 5.77$ & 0.73 & $3.75 \pm 0.97$ & $29.10 \pm 6.81$ \\
\hline MW-C79 & $93.33 \pm 5.77$ & 0.8 & $2.92 \pm 0.43$ & 0.00 \\
\hline MW-C81 & $100.00 \pm 0.00$ & 0.83 & $0.02 \pm 0.12$ & $35.44 \pm 3.30$ \\
\hline MW-M10 & $93.33 \pm 5.77$ & 0.67 & $0.22 \pm 0.19$ & $39.05 \pm 1.09$ \\
\hline MW-M13 & $96.67 \pm 5.77$ & 0.43 & $0.61 \pm 0.75$ & $36.29 \pm 1.73$ \\
\hline MW-M14 & $90.00 \pm 10.00$ & 0.47 & $0.44 \pm 0.14$ & $10.67 \pm 1.15$ \\
\hline MW-M15 & $93.33 \pm 5.77$ & 0.23 & $1.08 \pm 0.58$ & $48.57 \pm 6.55$ \\
\hline MW-M17 & $96.67 \pm 5.77$ & 0.40 & $1.75 \pm 0.97$ & $31.43 \pm 4.90$ \\
\hline MW-M19 & $100.00 \pm 0.00$ & 0.10 & $4.14 \pm 0.89$ & $29.52 \pm 1.71$ \\
\hline MW-M20 & $96.67 \pm 5.77$ & 0.73 & $1.03 \pm 0.18$ & $33.73 \pm 3.54$ \\
\hline MW-M4 & $100.00 \pm 0.00$ & 0.77 & $0.07 \pm 0.10$ & $2.72 \pm 0.25$ \\
\hline MW-M5 & $86.67 \pm 11.55$ & 0.27 & $0.62 \pm 0.05$ & 0.00 \\
\hline MW-M9 & $100.00 \pm 0.00$ & 0.37 & $0.50 \pm 0.44$ & $35.49 \pm 1.56$ \\
\hline SBC-C23 & $96.67 \pm 5.77$ & 0.57 & $0.16 \pm 0.25$ & $35.24 \pm 6.44$ \\
\hline Control & $100.00 \pm 0.00$ & - & - & $0.95 \pm 1.65$ \\
\hline
\end{tabular}


Table 4. Resistance patterns of 28 cellulase-producing marine bacteria according to antimicrobial susceptibility test using 30 kinds of antibiotics. 


\begin{tabular}{|c|c|c|c|c|c|c|c|c|}
\hline \multirow[t]{2}{*}{ Antibiotic tested } & & \multicolumn{3}{|c|}{$\begin{array}{l}\text { Cellulolytic marine bacteria } \\
(\%)\end{array}$} & \multicolumn{3}{|c|}{ Susceptibility in genus level (\%) } & \multirow[t]{2}{*}{$\begin{array}{l}\text { MAR } \\
\text { Index }\end{array}$} \\
\hline & & $S$ & 1 & $\mathrm{R}$ & Bacillus & Vibrio & Micrococcus & \\
\hline Penicillin & PEN & $7.14 \%$ & $3.57 \%$ & $89.29 \%$ & $4.55 \%$ & $25.00 \%$ & $0.00 \%$ & 0.89 \\
\hline Ampicillin & AMP & $17.86 \%$ & $17.86 \%$ & $64.29 \%$ & $13.64 \%$ & $50.00 \%$ & $0.00 \%$ & 0.64 \\
\hline Amoxicillin & AMX & $35.71 \%$ & $3.57 \%$ & $60.71 \%$ & $31.82 \%$ & $50.00 \%$ & $50.00 \%$ & 0.61 \\
\hline Oxacillin & OXA & $10.71 \%$ & $0.00 \%$ & $89.29 \%$ & $4.55 \%$ & $50.00 \%$ & $0.00 \%$ & 0.89 \\
\hline Piperacillin & PIP & $10.71 \%$ & $0.00 \%$ & $89.29 \%$ & $9.09 \%$ & $25.00 \%$ & $0.00 \%$ & 0.89 \\
\hline Carbenicillin & CAR & $10.71 \%$ & $7.14 \%$ & $82.14 \%$ & $9.09 \%$ & $25.00 \%$ & $0.00 \%$ & 0.82 \\
\hline Cefazolin & CFZ & $17.86 \%$ & $21.43 \%$ & $60.71 \%$ & $13.64 \%$ & $50.00 \%$ & $0.00 \%$ & 0.61 \\
\hline Cefalexin & LEX & $10.71 \%$ & $7.14 \%$ & $82.14 \%$ & $9.09 \%$ & $25.00 \%$ & $0.00 \%$ & 0.82 \\
\hline Cefoxitin & FOX & $14.29 \%$ & $67.86 \%$ & $17.86 \%$ & $9.09 \%$ & $50.00 \%$ & $0.00 \%$ & 0.18 \\
\hline Ceftriaxone & CRO & $7.14 \%$ & $78.57 \%$ & $14.29 \%$ & $0.00 \%$ & $25.00 \%$ & $50.00 \%$ & 0.14 \\
\hline Streptomycin & STR & $7.14 \%$ & $7.14 \%$ & $85.71 \%$ & $4.55 \%$ & $0.00 \%$ & $50.00 \%$ & 0.86 \\
\hline Kanamycin & KAN & $39.29 \%$ & $3.57 \%$ & $57.14 \%$ & $0.00 \%$ & $0.00 \%$ & $50.00 \%$ & 0.57 \\
\hline Gentamicin & GEN & $17.86 \%$ & $25.00 \%$ & $57.14 \%$ & $13.64 \%$ & $25.00 \%$ & $50.00 \%$ & 0.57 \\
\hline Amikacin & AMK & $3.57 \%$ & $21.43 \%$ & $75.00 \%$ & $0.00 \%$ & $0.00 \%$ & $50.00 \%$ & 0.75 \\
\hline Neomycin & NEO & $7.14 \%$ & $53.57 \%$ & $39.29 \%$ & $0.00 \%$ & $25.00 \%$ & $50.00 \%$ & 0.39 \\
\hline Spectinomycin & SPE & $7.14 \%$ & $10.71 \%$ & $82.14 \%$ & $0.00 \%$ & $25.00 \%$ & $50.00 \%$ & 0.82 \\
\hline Oxytetracycline & OXY & $3.57 \%$ & $57.14 \%$ & $39.29 \%$ & $0.00 \%$ & $0.00 \%$ & $50.00 \%$ & 0.39 \\
\hline Tetracycline & TCY & $3.57 \%$ & $3.57 \%$ & $92.86 \%$ & $0.00 \%$ & $0.00 \%$ & $50.00 \%$ & 0.93 \\
\hline Minocycline & MNO & $14.29 \%$ & $21.43 \%$ & $64.29 \%$ & $9.09 \%$ & $25.00 \%$ & $50.00 \%$ & 0.64 \\
\hline Doxycycline & DOX & $17.86 \%$ & $10.71 \%$ & $71.43 \%$ & $9.09 \%$ & $50.00 \%$ & $50.00 \%$ & 0.71 \\
\hline Florfenicol & FFC & $17.86 \%$ & $32.14 \%$ & $50.00 \%$ & $9.09 \%$ & $50.00 \%$ & $50.00 \%$ & 0.50 \\
\hline Chloramphenicol & $\mathrm{CHL}$ & $82.14 \%$ & $14.29 \%$ & $3.57 \%$ & $77.27 \%$ & $100.00 \%$ & $100.00 \%$ & 0.04 \\
\hline Furazolidone & FRZ3 & $32.14 \%$ & $50.00 \%$ & $17.86 \%$ & $31.82 \%$ & $50.00 \%$ & $0.00 \%$ & 0.18 \\
\hline Norfloxacin & NOR & $28.57 \%$ & $46.43 \%$ & $25.00 \%$ & $27.27 \%$ & $25.00 \%$ & $50.00 \%$ & 0.25 \\
\hline Levofloxacin & LVX & $14.29 \%$ & $28.57 \%$ & $57.14 \%$ & $13.64 \%$ & $0.00 \%$ & $50.00 \%$ & 0.57 \\
\hline Ofloxacin & OFX & $28.57 \%$ & $21.43 \%$ & $50.00 \%$ & $27.27 \%$ & $25.00 \%$ & $50.00 \%$ & 0.50 \\
\hline Ciprofloxacin & CIP & $14.29 \%$ & $35.71 \%$ & $50.00 \%$ & $9.09 \%$ & $25.00 \%$ & $50.00 \%$ & 0.50 \\
\hline Erythromycin & ERY & $7.14 \%$ & $7.14 \%$ & $85.71 \%$ & $0.00 \%$ & $25.00 \%$ & $50.00 \%$ & 0.86 \\
\hline Azithromycin & AZM & $7.14 \%$ & $7.14 \%$ & $85.71 \%$ & $0.00 \%$ & $25.00 \%$ & $50.00 \%$ & 0.86 \\
\hline
\end{tabular}


Note: S: sensitive to tested antibiotic; I: intermediate resistant to tested antibiotic; R: resistant to tested antibiotic.

\section{Figures}

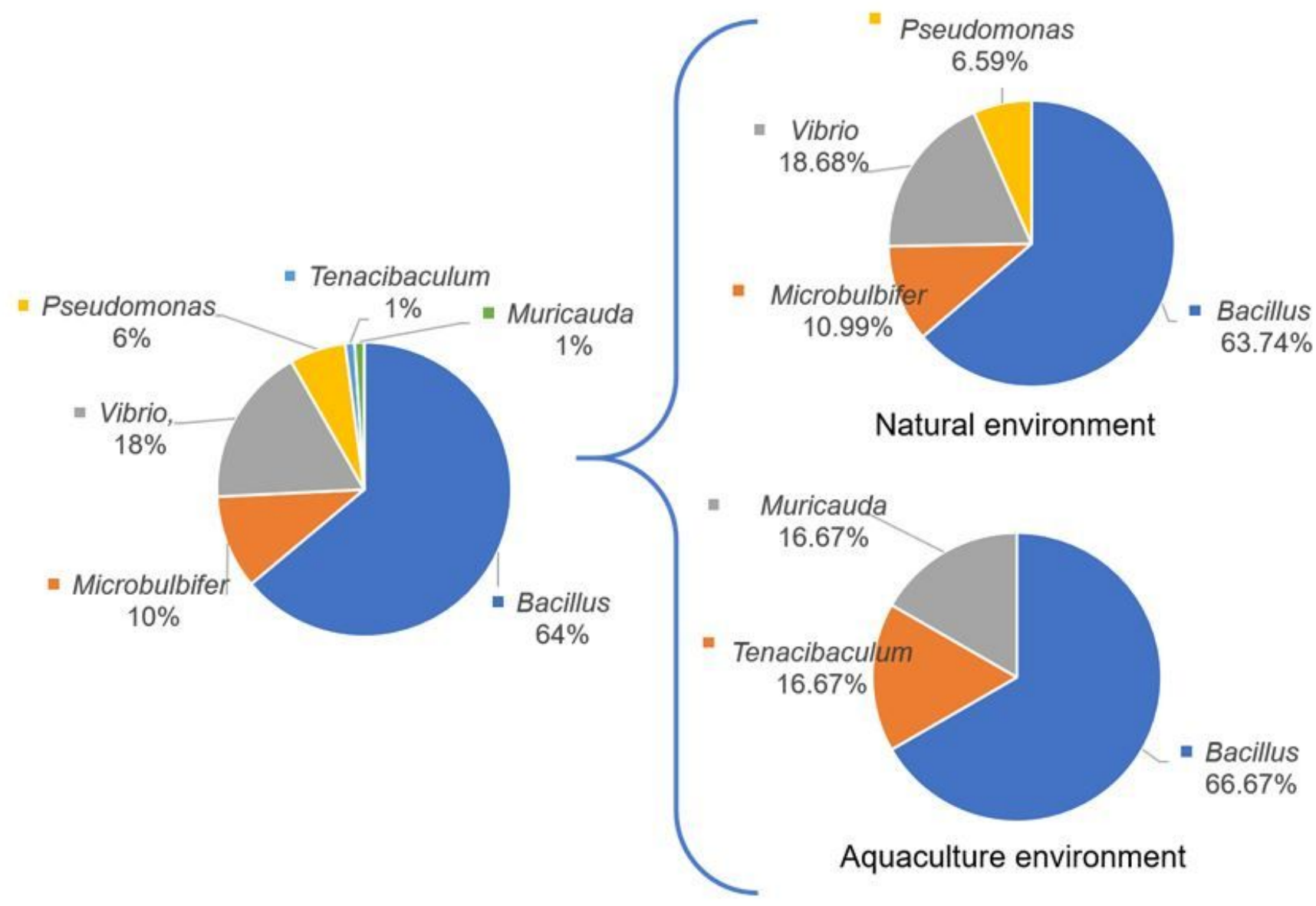

\section{Figure 1}

Diversity of 97 cellulolytic marine bacteria in the study sites.

\section{Supplementary Files}

This is a list of supplementary files associated with this preprint. Click to download.

- SupportingInformation.docx 